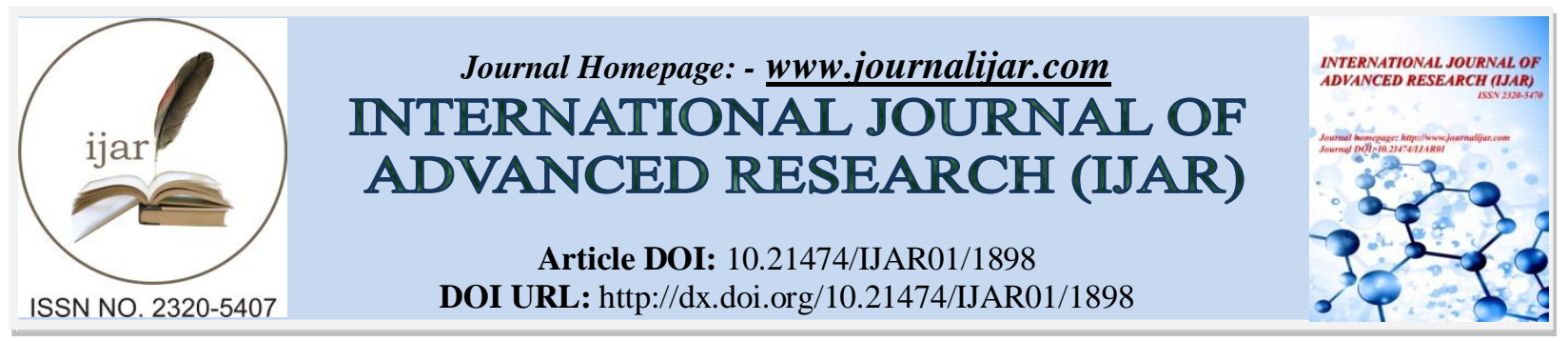

RESEARCH ARTICLE

\title{
SEAWEEDS AS BIOINDICATORS OF HEAVY METALS POLLUTION IN TARUT BAY SAUDI ARABIA.
}

\author{
Mohamed Guitouni*1,2, Ali Al Madan ${ }^{2}$ and Sami Shabeeb Al-Shabeeb ${ }^{2}$. \\ 1. National Institute of Research and Physico-Chemical Analysis, Technological Pole Sidi Thabet 2020, Aryanah, \\ Tunisia. \\ 2. Fisheries Research Center, Eastern Province, Kingdom of Saudi Arabia.
}

\section{Manuscript Info (.......................... \\ Manuscript History \\ Received: 16 August 2016 \\ Final Accepted: 22 September 2016 \\ Published: October 2016}

Key words:-

Heavy metals, seaweeds, bioindicators, accumulation.

\section{Abstract}

Seaweeds have an important role in the marine environment as bioindicator of heavy metals pollution. In this study, we investigated the accumulation of heavy metals ( $\mathrm{As}, \mathrm{Ni}, \mathrm{Zn}, \mathrm{Cr}, \mathrm{Fe}$, and $\mathrm{Hg}$ ) in seaweeds species such as Ancorina alata, Sargassum sp., Dictyota sp., Dictyota dichotoma, Platoma heteromorphum, Liagora viscid and Codium isthmocladum in Tarut Bay, Eastern province - kingdom of Saudi Arabia. The results find for different species of seaweeds showed the presence of nickel, iron and mercury with less concentrations than arsenic, zinc and chromium. Arsenic was the most element accumulated in the different species of seaweeds (between 11 ppm and 54 ppm in different species for seaweeds).

Copy Right, IJAR, 2016,. All rights reserved.

\section{Introduction:-}

Coastal and marine environments throughout the world suffer from high pollution caused by the humans. Heavy metals are considered a major anthropogenic contaminants in the coastal and marine environments throughout the world (Ruilian et al., 2008). They are a serious threat to living organisms and natural ecosystems due to their toxicity (DeForest et al., 2007). Heavy metals can contribute to the degradation of marine ecosystems by reducing the diversity of species and through the accumulation of metals in living organisms and food chains (Hosono et al., 2011). The anthropogenically sources of this pollution are the petroleum industries, mining, municipal waste and wastewater (Fu and Wang, 2011; Al-Khateeb \& Leilan, 2005). The contamination of heavy metals in the coastal and marine environment of the Arabian Gulf is becoming a more serious threat to the marine environment. The Arabian Gulf is a semi-enclosed sea located in the subtropical zone and characterized by marked changes in sea temperatures and high salinities. It is relatively a shallow basin with an average depth of $35 \mathrm{~m}$ (Sheppard et al., 2010). The growing importance of heavy metals disrupt the environment is particularly evident in aquatic systems. Although most investigations were made on microalgae, algae and macrophytes and they are considered valuable indicators because of their accumulation capacity (Munda, 1993; Whitton, 1984; Maeda and Sakaguchi, 1990; Haritonidis and Malea, 1999; Conti and Cecchetti, 2003; Kamala-Kannan et al., 2008). Seaweeds are excellent agents of filtering the metals like arsenic, zinc, iron, nickel and mercury from seawater. They remove the toxic materials from the environment and accumulate in the body cell. The absorption of metals present in the seaweed depends on the surface reaction in which metals absorbed through electrostatic attraction to negatives sites. This is independent of factors influencing metabolism such as $\mathrm{pH}$, temperature, light or age of the plant, but it is inclined by the virtual abundance of elements in water (Sanchez-Rodriguez et al., 2001). 
In this study, an assay was made to find the possibility of using the seaweeds as biomonitoring agents to evaluate various heavy metals such as $\mathrm{As}, \mathrm{Hg}, \mathrm{Ni}, \mathrm{Fe}, \mathrm{Cr}$ and $\mathrm{Zn}$ which are released from the activity of petroleum industries, discharge of industrial waste and oil spills from ships (Literathy et al., 2002). Seaweeds samples are taken from Tarut Bay, Eastern Province-Saudi Arabia,

\section{Material and Methods:-}

The samples of seaweeds are collected from Tarut Bay, Eastern Province-Saudi Arabia, during the period from April 2015 to june 2015. Tarut Bay is located along the coastline of the Arabian Gulf. Tarut Bay extends from the King Abdulaziz seaport of Dammam and end at Ras Tanura, covering an area of $410 \mathrm{k}^{2}$ as shown in Figure 1.

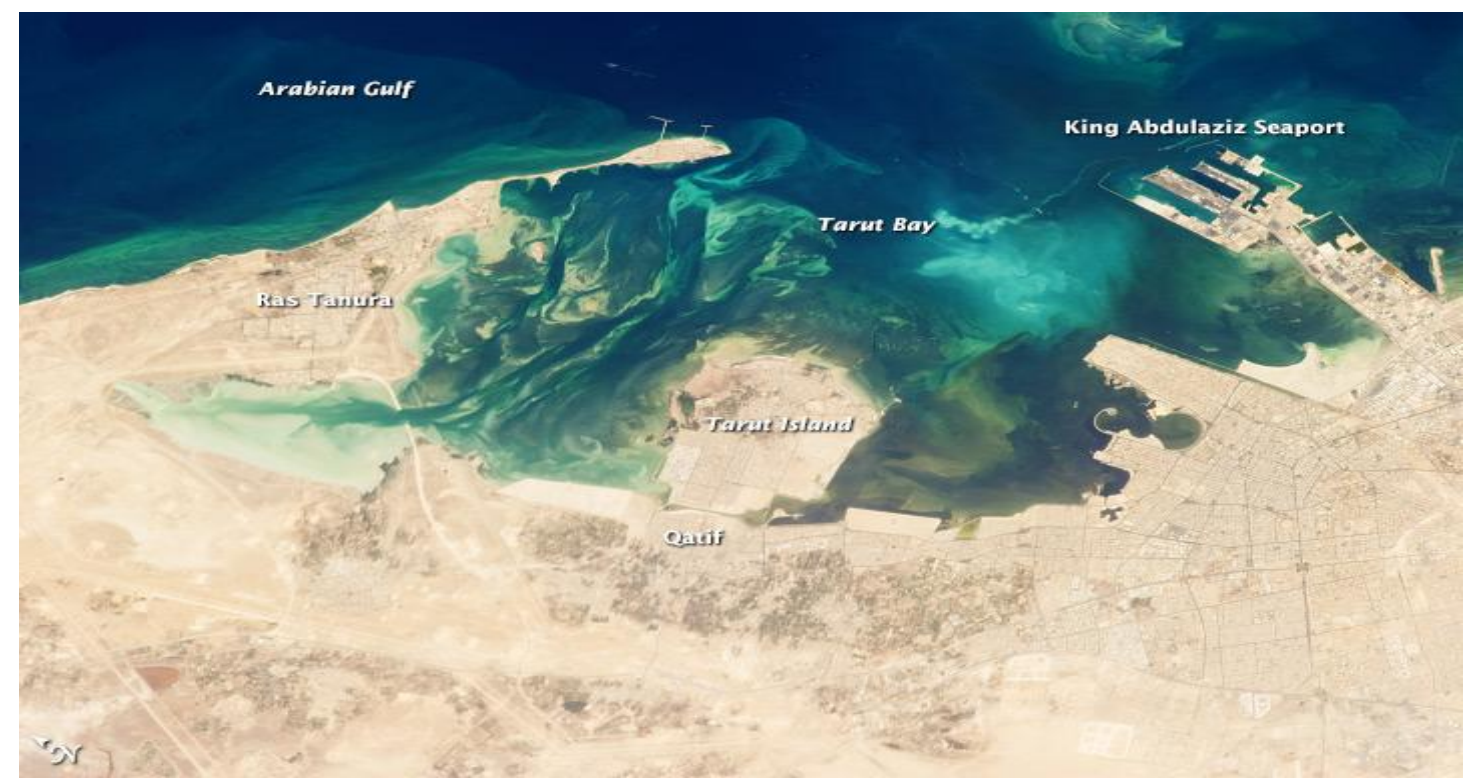

Figure 1:- Tarut Bay (picture from earth observatory, http://earthobservatory.nasa.gov/IOD/view.php?id=81255)

The samples of seaweeds have been used to determine the concentrations of six heavy metals: Arsenic, Nickel, Zinc, Iron, chromium and mercury.

Seaweeds have been dried in electrical oven. Then digests with $8 \mathrm{ml} \mathrm{HNO3} \mathrm{(65 \% )} \mathrm{in} \mathrm{a} \mathrm{microwave} \mathrm{mineralization}$ (microwave Milestone Ethos one). The heavy metals were determined by the Inductively Coupled Plasma-Optical Emission Spectrometer (ICP-OES ; Varian 720-ES) and they were quantified in ppm.( Sawidis et al., 2001; Brown et al., 1999; Al-Homaidan, 2008)

Mercury analysis has been realized using the Direct Mercury Analyser (DMA-80, Milestone).

\section{Identification of Seaweeds:-}

The collected seaweeds were identified, we have the following species: ancorina sponge (Ancorina alata); Sargassum sp.; Dictyota sp.; Dictyota.dichotoma; Platoma heteromorphum; Liagora viscida; Codium isthmocladum.

\section{Results:-}

The analysis of seaweeds samples for heavy metals accumulation showed that seaweeds have a high capacity to accumulate heavy metals present in the marine environment. The concentration of heavy metals accumulated differ from one plant to another, we see that the Liagora viscida species accumulate more heavy metals than other species. The concentrations of heavy metals accumulated by seaweeds is shown in Table 1 and Figure 2. 
Table 1:- Heavy Metal accumulated in Seaweeds (ppm)

\begin{tabular}{|l|l|l|l|l|l|l|}
\hline Species & $\mathrm{As}$ & $\mathrm{Hg}$ & $\mathrm{Fe}$ & $\mathrm{Ni}$ & $\mathrm{Cr}$ & $\mathrm{Zn}$ \\
\hline Ancorina alata & 11.879 & 0.1427 & 0.2038 & 0.2223 & 1.4845 & 6.3689 \\
\hline Sargassum sp. & 29.945 & 0.1213 & 0.4813 & 0.4410 & 2.0160 & 12.8539 \\
\hline Dictyota sp. & 12.210 & 0.1420 & 0.3936 & 0.7932 & 1.3411 & 7.6541 \\
\hline Dictyota.dichotoma & 12.209 & 0.1530 & 0.3938 & 0.3883 & 1.3866 & 10.8091 \\
\hline Platoma heteromorphum & 54.340 & 0.2105 & 0.1322 & 0.1997 & 0.4517 & 5.1731 \\
\hline Liagora viscida & 12.089 & 1.1390 & 1.0655 & 1.1747 & 3.8495 & 16.2955 \\
\hline Codium isthmocladum & 44.873 & 0.1954 & 0.4021 & 0.3745 & 1.2397 & 11.1458 \\
\hline
\end{tabular}

\section{$\mathrm{Hg}$}
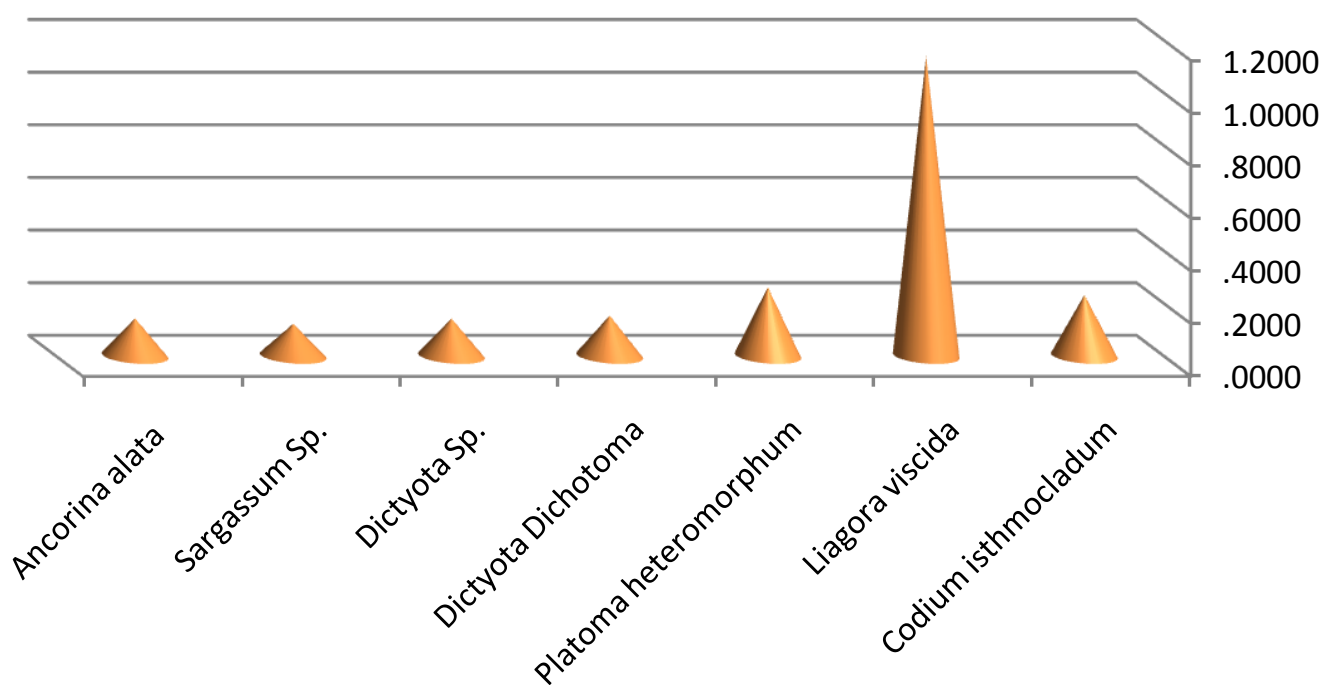

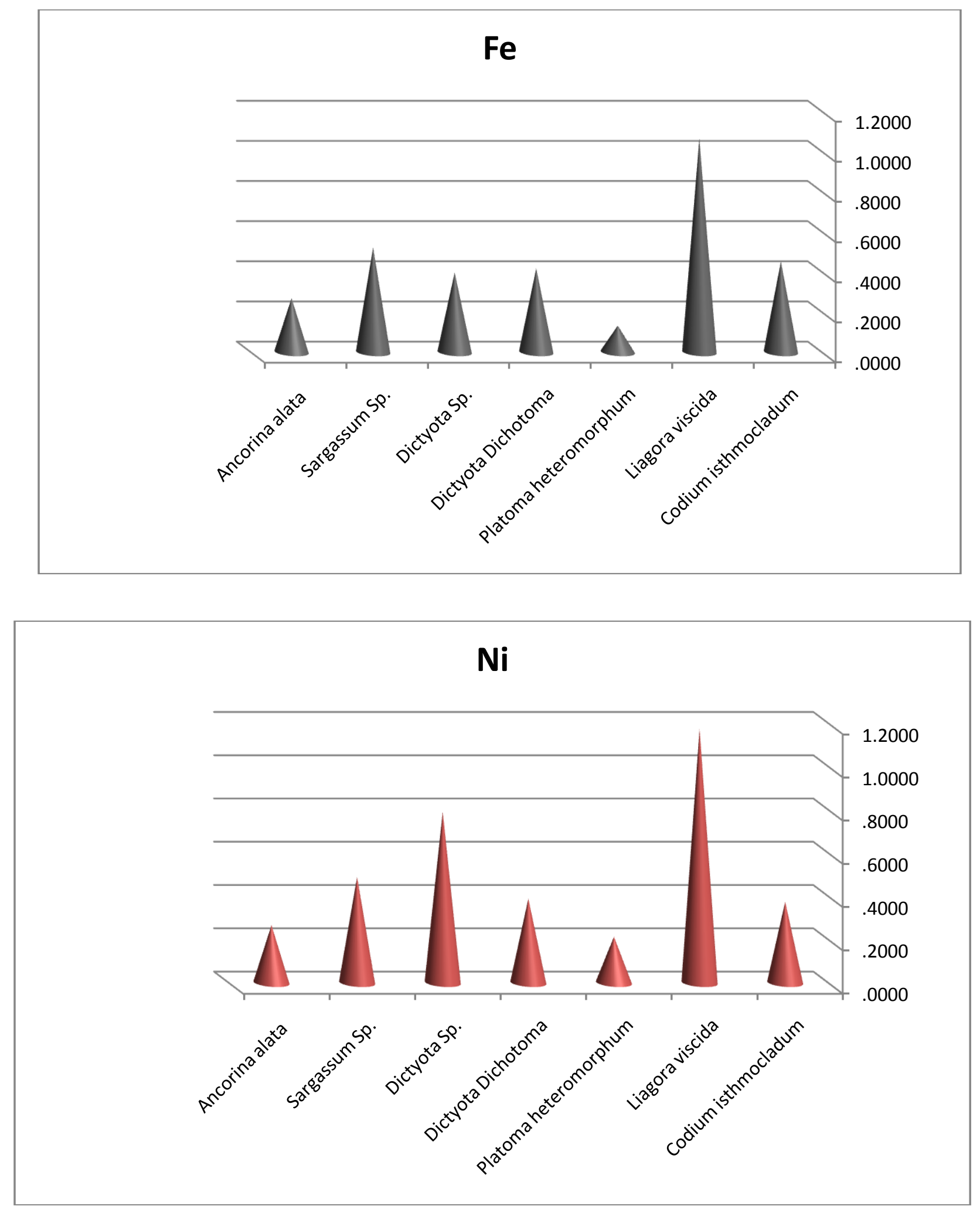


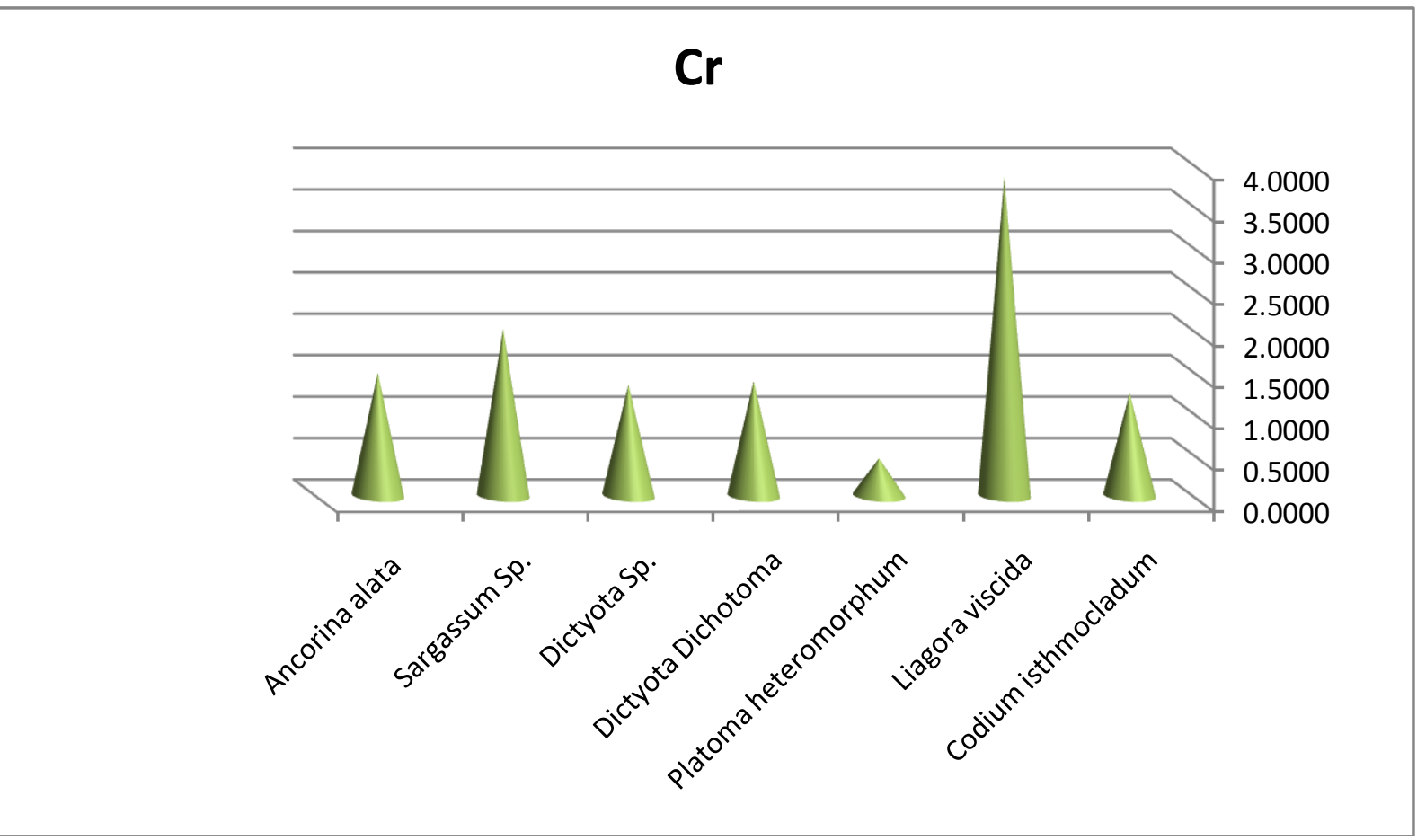

\section{Zn}
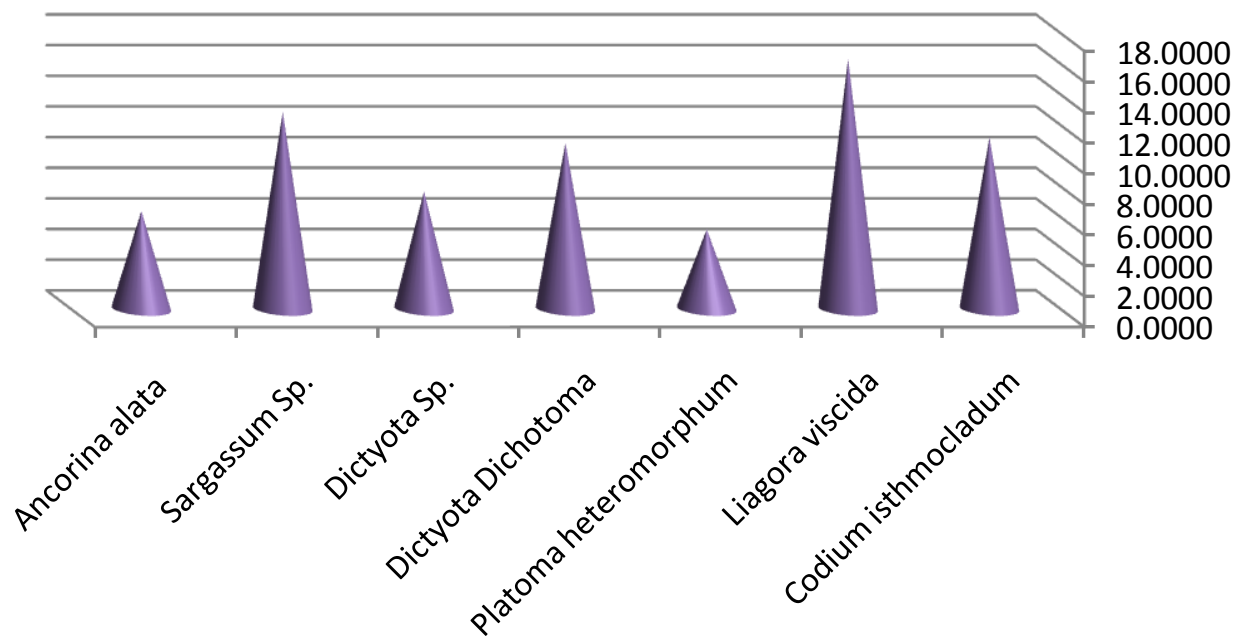


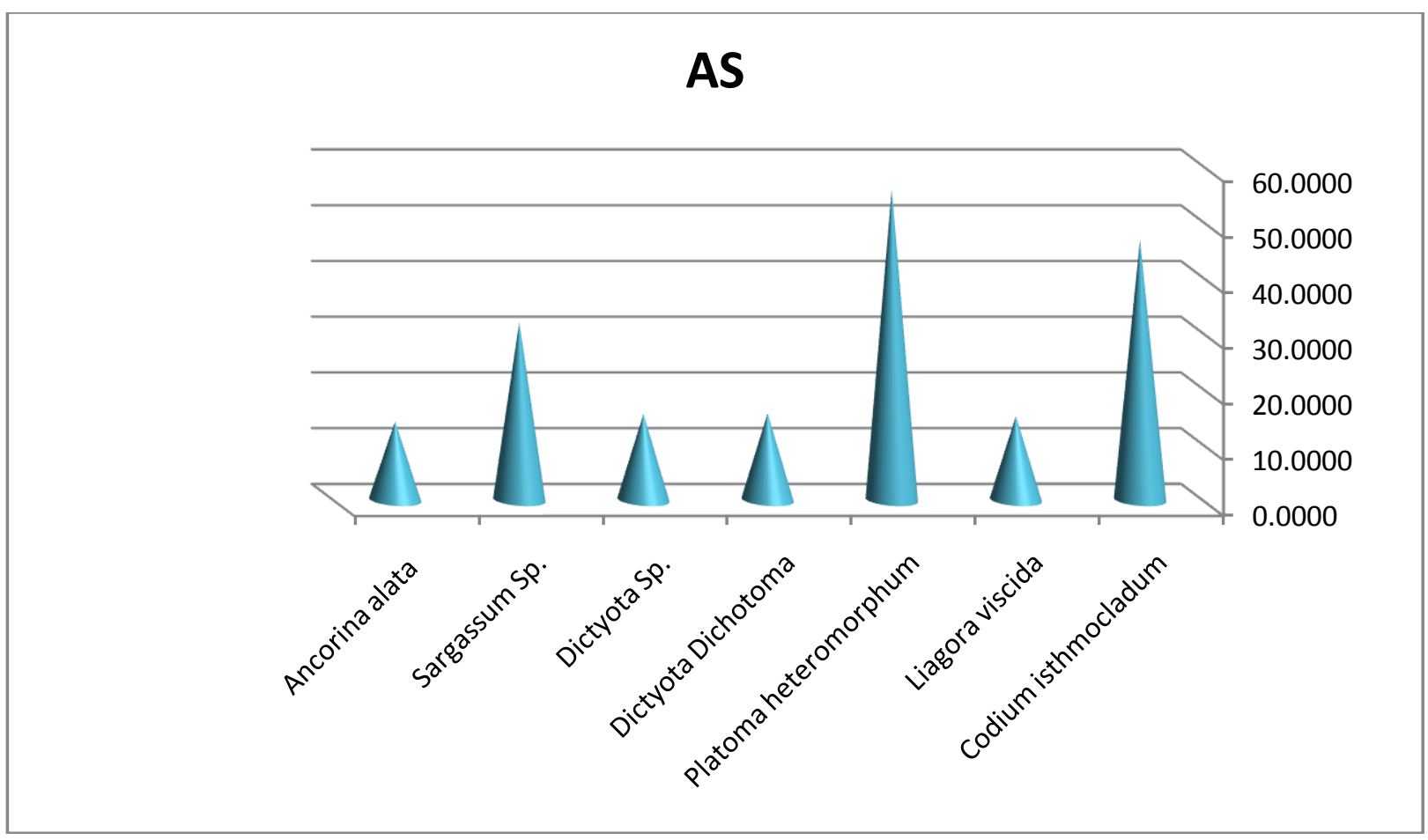

Figure 2:- Accumulation of heavy metals in seaweeds (ppm)

We calculated also the capability of absorbing and accumulating (in percent) for the six heavy metals ( $\mathrm{As}, \mathrm{Cr}, \mathrm{Ni}$, $\mathrm{Hg}, \mathrm{Zn}, \mathrm{Fe}$ ) by seaweeds studied. The results are presented in Figure 3

\section{$\mathrm{Hg}$}

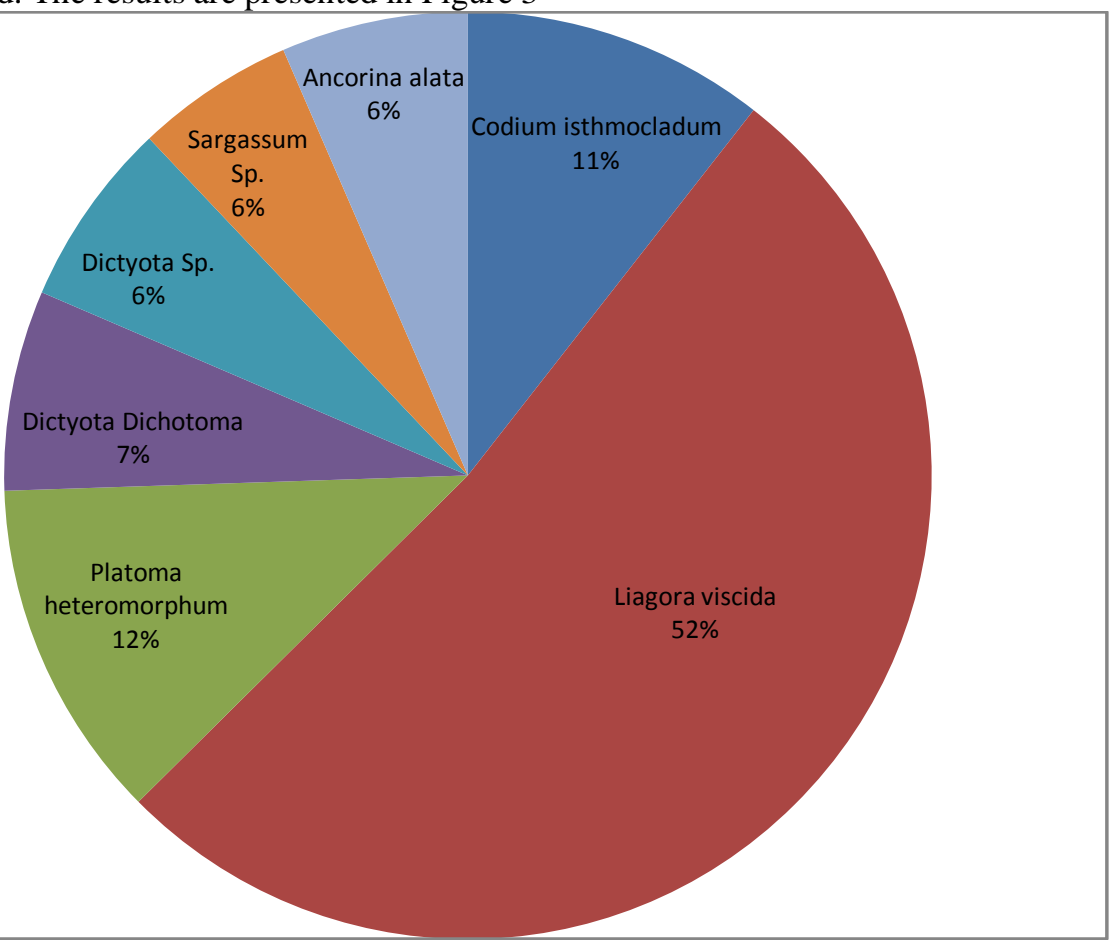



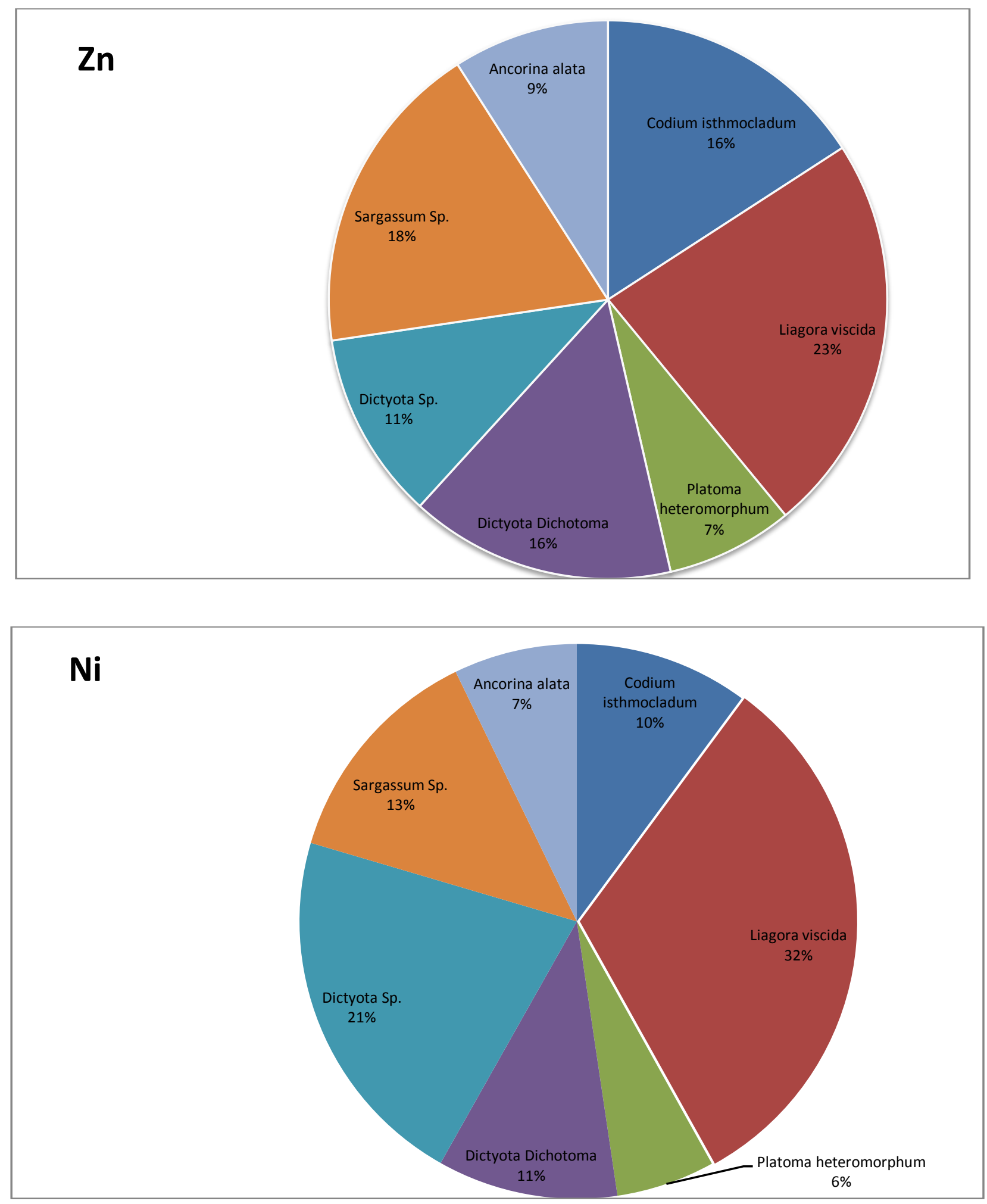

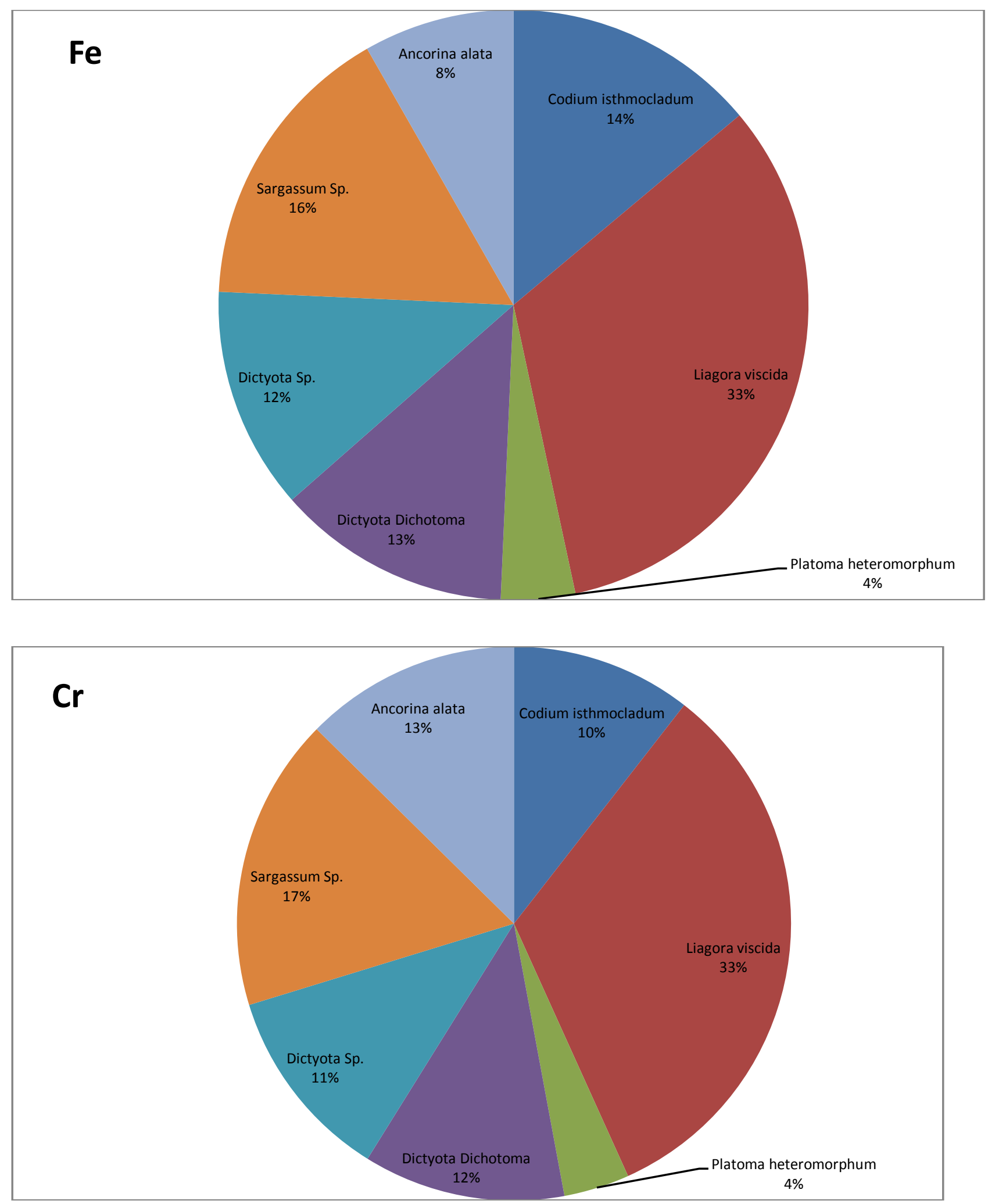


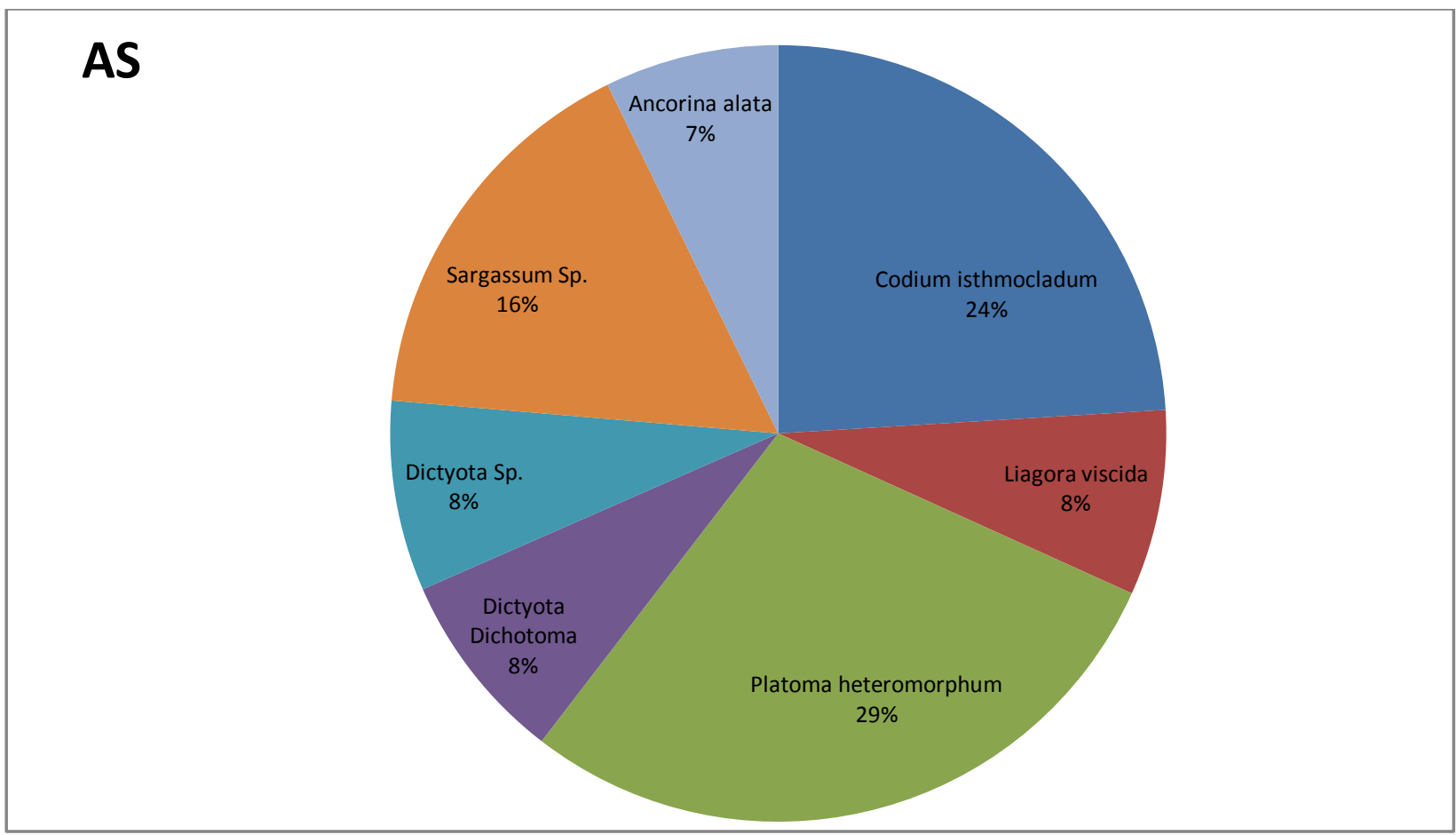

Figure 3:- Percentage of accumulation of heavy metals in seaweeds.

\section{Discussion:-}

Although some studies have indicated that the heavy metals in seaweeds were on the underside of the values reported by other studies in ocean areas (Kureishy, 1991; El-Sayed and Dorgham,1994). Later studies in the Arabian Gulf have detected trend of increasing in metal concentrations (Kureishy et al., 1995; Buo-Olayan and Subrahmanyam 1996; Mohamed, 2002; Al-Homaidan, 2006, 2007).

In this study, the results find for different species of seaweeds showed the presence of nickel, iron and mercury with less concentrations than arsenic, zinc and chromium. we see that the Liagora viscida species accumulate more heavy metals than other species. It was observed that arsenic was the most element accumulated in the different species of seaweeds (from $11 \mathrm{ppm}$ to $54 \mathrm{ppm}$ in different spesies for seaweeds), this can be explained by that the marine organisms normally contain arsenic residues ranging from less than 1 to more than $100 \mathrm{mg} / \mathrm{kg}$, predominantly as organic arsenic species such as arsenosugars (macroalgae) and arsenobetaine (invertebrates and fish). The bioaccumulation of organic arsenic compounds, after their biogenesis from inorganic forms, occurs in aquatic organisms. Bioconcentration factors (BCFs) in freshwater invertebrates and fish for arsenic compounds are lower than for marine organisms.

It clearly demonstrated that the seaweeds are considered valuable indicators because of their accumulation capacity of heavy metals, and can we used the seaweeds in phytoremediation (Salt et al., 1998) to absorb and remove contaminants from polluted soil and water is an efficient and friendly mechanism for the environment, such as mangrove (Avicennia marina) (Mohamed et al., 2016; Suresh \& Ravishankar, 2004; Isaiah et al., 2011) for the marine environment. Further the seaweeds can be used as biological filters for the water used in fish farm to absorb and accumulate contaminants especially heavy metals.

\section{Conclusion:-}

We confirm in this study that seaweeds can used as biomonitoring agents to evaluate-heavy metals pollution in marine environment. And they are considered valuable indicators because of their accumulation capacity of heavy metals. Seaweeds can be used in the phytoremediation system for cleaning the marine environment from pollutant and especially from heavy metals and can be used also as biological filters for the water used in fish farm. 


\section{References:-}

1. Al-Homaidan, A. (2006): Brown algae as bioindicators of heavy metal pollution along Saudi coast of the Arabian Gulf. Saudi J. Biol. Sci., 13: 99-103.

2. Al-Homaidan, A. (2007): Heavy metal concentrations in three species of green algae from the Saudi coast of the Arabian Gulf. Int. J. Food Agric. Environ., 5 (3-4): 354-358.

3. Al-Homaidan, A. (2008): Accumulation of nickel by marine macroalgae from the Saudi coast of the Arabian Gulf. J. Food Agri. Environ., 6: 148-151.

4. Al-Khateeb, S.A., \& Leilan, A.A. (2005): Heavy Metals Accumulation in the Natural Vegetation of Eastern Province of Saudi Arabia. Journal of Biological Sciences., 5(6): 707-712.

5. Buo-Olayan, A., \& Subrahmanyam, M. (1997): Accumulation of copper, nickel. Lead and zinc by snail, Lunella coronatus and pearl oyster, Pinctada radiata from the Kuwait coast before and after the Gulf war oil spill. Sci. Total Environ., 197: 161-165.

6. Brown, M.T., Hodgkinson, W.M., \& Hurd, C.L. (1999): Spatial and temporal variations in the copper and zinc concentrations of two green seaweeds from Otago Harbour, New Zealand. Mar. Environ. Res., 47: 175-184.

7. Conti, M.E., \& Cecchetti, G. (2003): A biomonitoring study: trace metals in algae and molluscs from Tyrrhenian coastal areas. Environ. Res., 93: 99-112.

8. DeForest, D., Brix, K., \& Adams, W. (2007): Assessing metal bioaccumulation in aquatic environments: The inverse relationship between bioaccumulation factors, trophic transfer factors and exposure concentration. Aquat. Toxicol., 84: 236-246.

9. El-Sayed, M., \& Dorgham M (1994): Trace metals in macroalgae from the Qatari coastal water. J. King Abdulaziz Univ.: Mar. Sci., 5: 13-24.

10. Fu, F., \& Wang, Q. (2011): Removal of heavy metal ions from wastewaters: a review. J.Environ. Manage., 92: 407-418.

11. Haritonidis, S., \& Malea, P. (1999): Bioaccumulation of metals by the green alga Ulva rigida from Thermaikos Gulf, Greece. Environ. Pollut., 104: 365-372.

12. Hosono, T., Su, C., Delinom, R., Umezawa, Y., Toyota, T., Kaneko, S., \& Taniguchi, M. (2011): Decline in heavy metal contamination in marine sediments in Jakarta Bay,Indonesia due to increasing environmental regulations. Estuar. Coast. Shelf Sci., 92: 297-306.

13. Isaiah, N.K., Poliyaparambil, R. S., Rita, N. K., George, B., \& Viyol, S. (2011): An Assessment of the Accumulation Potential of $\mathrm{Pb}, \mathrm{Zn}$ and $\mathrm{Cd}$ by Avicennia marina (Forssk.) Vierh. in Vamleshwar Mangroves, Gujarat, India. University of Agricultural Sciences and Veterinary Medicine, Cluj-Napoca, Romania.

14. Kamala-Kannan, S., Batvari, B. P. D., Lee, K. J., Kannan, N., Krishnamoorthy, R., Shanthi, K., \& Jayaprakash, M. (2008): Assessment of heavy metals $(\mathrm{Cd}, \mathrm{Cr}$ and $\mathrm{Pb}$ ) in water sediment and seaweed (Ulva lactuca) in the Pulicat Lake, South East India. Chemosphere., 71: 1233-1240.

15. Kureishy, T. (1991): Heavy metals in algae around the coast of Qatar. Mar. Pollut. Bull., 22: 414-416.

16. Kureishy, T., Abdelmoati, M., \& Al-Muftah, A. (1995): Marine algae as biondicators of pollution levels in the Arabian Gulf. Qatar Univ. Sci. J., 15: 215-221.

17. Literathy, P., Khan, N.Y., \& Linden, O. (2002): Oil and Petroleum industry. The Gulf ecosystem: Health and sustainability. Leiden: Backhuys, pp. 127-156.

18. Maeda, S., \& Sakaguchi, T. (1990): Accumulation and detoxification of toxic metal elements by algae. In: I. Akatsuka, Introduction to applied Phycology, The Hague: Academic Publishing bv, pp: 109-136. ISBN 905103-052-5.

19. Mohamed, A. (2002): Trace metal concentrations in marine algae Hormophysa triquetra, Bahrain Coastline (Arabian Gulf). Pollut. Res., 21 (4): 397-402.

20. Mohamed, G., Mostafa, G. \& Nabil, F. (2016): Accumulation of heavy metals in Mangroves (Avicennia marina) from Syhat and Safwa region, Tarut Bay Saudi Arabia. Int. J. of Adv. Res., 4 (7): 1811-1816.

21. Munda, I. M. (1993): Eutrofication und Truce Metal Cycling in Estuarine and Lagoons. Thessaloniki, Greece. pp. 45565 .

22. Ruilian, Y., Xing, Y., Yuanhui, Z., Gongren, H., \& Xianglin, T. (2008): Heavy metal pollution in intertidal sediments from Quanzhou Bay. China. J. Environ. Sci., 20: 664-669.

23. Salt, D.E., Smith, R.D., \& Raskin, I. (1998): Pytoremediation. Annual Review of Plant Physiology and Plant Molecular Biology., 49(1): 643-668.

24. Sanchez-Rodriguez, Huerta-Diaz, M.A., Choumiline, E., Holguin-Quinones, O., \& Zertuche-Gonzalez, J.A. (2001): Elemental concentrations in different species of seaweeds from Loreto Bay, Baja California Sur, Mexico: implications for the geochemical control of metals in algal tissue. Env. Pol., 114 (2): 145-160. 
25. Sawidis, T., Brown, M.T., Zachariadis, G., \& Stratis, I. (2001): Trace metal concentrations in marine macroalgae from different biotopes in the Aegean Sea. Environ. Inter., 27: 43-47.

26. Sheppard, C., Al-Husiani, M., Al-Jamali, F., Al-Yamani, F., Baldwin, R., Bishop, J., et al. (2010): The Gulf: a young sea in decline. Mar. Pollut. Bull., 60: 3-38.

27. Suresh, B., \& Ravishankar, G.A. (2004): Phytoremediation - a novel and promising approach for environmental clean-up. Critical Reviews in Biotechnology., 24(2-3): 97-124.

28. Whitton, B.A. (1984): Algae as monitors of heavy metals in freshwaters. In: L.E. Shubert, Algae as ecological indicators. London: Academic Press, Inc. pp: 257-280. ISBN 0-12-640620-0. 